\title{
A mortality study of Finnish pulp and paper workers
}

\author{
P JÄPPINEN
}

From Enso-Gutzeit Oy, Occupational Health Centre, SF-55800 Imatra, Finland

ABSTRACT Mortality among workers in the Finnish pulp and paper industry was evaluated in a retrospective cohort study of 3520 workers who had been employed continuously for at least one year between 1945 and 1961. Six subcohorts were formed according to six work areas: sulphite, sulphate, paper, and board mills, maintenance department, and power plant. National mortality rates were used for comparison. The mortality of a cohort of 1290 sawmill workers was also studied in order to have a socially, geographically, and occupationally similar group without the exposures typical of the pulp and paper industry for comparison. Smoking habits were surveyed. Mortality was followed up until 31 December 1981. Overall mortality for the entire cohort did not differ from that expected (1044 obs, 1029.4 exp, SMR 101), but there was an excess of deaths from diseases of the circulatory system among the men (489 obs, 404.9 exp, SMR 121). This was due to the excess of deaths from ischaemic heart disease found among the men at the sulphite, sulphate, and paper mills, maintenance department, and power plant, but not at the sawmill. The existing smoking data did not explain this finding and it may therefore be associated with occupational exposures.

There is limited information on the mortality of pulp and paper workers despite the significance of this industry to the economy of many countries. In Finland 44000 workers were employed in the pulp and paper industry in $1982 .{ }^{1}$ In the United States the number of production workers in the industry was more than 540000 in $1979^{2}$ and in the United Kingdom it was 39000 in $1981 .^{3}$ Published studies have shown an increased risk of neoplasms of the lymphatic system ${ }^{4-8}$ and also excesses of some other malignancies, especially lung cancer. ${ }^{9-11}$ Although potential carcinogens are used in the pulp and paper industry, ${ }^{12}$ the epidemiological data are as yet insufficient to evaluate the cancer risk of working in the industry. There is also a scarcity of information on deaths from other causes. In a follow up study of 271 pulp and paper workers a slight increase in overall mortality was found among the paper workers. ${ }^{13}$ A recent proportionate mortality study, conducted using the death records of 2113 members of a pulp and paper union, showed significant excesses of deaths due to cancer of the stomach, circulatory diseases, and accidents. ${ }^{14}$ It is hard to find an exposure to explain all these findings. The number of chemicals used in this industry, however, is so great that at least some of the excess mortality may have a recognisable cause at the workplace. One group of substances that is interesting on theoretical grounds is sulphur coms pounds. ${ }^{15}$ The present study was designed primarily to establish the risk of cancer among workers in the Finnish pulp and paper industry. At the same time it provided an opportunity to investigate the mortality of this group from causes other than cancer and the results are presented here.

\section{Materials and methods}

The material consisted of the workers at three pulp and paper mills owned by the same company in the province of Kymi in south eastern Finland. Two mills used the alkaline or sulphate pulping process and were still in operation. The third mill, in operation from 1910 to 1962 , had used the acidic or sulphite pulping process.

The workers were grouped into six subcohorts by work area: (1) sulphite mill, (2) sulphate mill, (3) paper mill, (4) board mill, (5) maintenance department, and (6) power plant. The six subcohorts have characteristic exposures (tables 1 and 2). Although the processes had been slightly modified, pulp, paper, and board were made in basically the same way throughout the study period.

The workers at a sawmill owned by the same company and located in the same province were included in the study to establish if mortality differed between 
workers in the chemical wood processing and mechanical wood processing industries. The workers at the sawmill were not completely free from chemical exposure to some familiar compounds, such as chlo-

Table 1 Occupational exposure to compounds in the pulp mills under study

Sulphite mill:

Sulphur, sulphur dioxide, ammonia, limestone, sulphurous acid, calcium bisulphite, calcium oxide, carbon monoxide, carbon dioxide, lignosulphonates, methanol, acetic acid, formic acid, formaldehyde, furaldehyde, cymene

Sulphate mill:

Cooking, washing, evaporation, recovery furnace-Hydrogen sulphide, dimethylsulphide, dimethyldisulphide, methylmercaptan, and other thiols; sodium hydroxide; sodium sulphide; sodium carbonate; sodium sulphate; terpenes; sulphuric acid; tall oil; anthraquinone (occasionally)

Causticising, lime kiln-Calcium oxide, calcium hydroxide, sodium carbonate, sodium hydroxide

Bleaching - Chlorine, chlorine dioxide, sodium hypochlorite, sodium hydroxide, chlorinated phenols, and other organic chlorine compounds

Exposure in both the sulphite and sulphate mills:

Wood handling - Wood dust, microbes (Aspergillus, Penicillium, etc)

Water treatment, machinery cleaning-Ammonia, hydrazine, hydrochloric acid, nitric acid, slime controlling agents (not regularly, same types as in paper manufacturing, table 2) Maintenance chemicals - Same as in paper manufacturing (table 2)

Power plant-Sulphur dioxide, organic sulphur compounds (sulphate process), water treatment agents (see above)

Table 2 Occupational exposure to compounds in the paper and board mills

Fillers: Kaolin, talc, calcium carbonate, titanium dioxide

Retention agents: Starch derivatives, acrylamide compounds, reaction products of epichlorohydrin

Sizes: Rosin soap, sodium aluminate, aluminium sulphate, starch, synthetic polymers, latexes

Other additives: Urea, urea formaldehyde resins

Dyes: Auramine (in the 1960s and early 1970s), rhodamine, methylviolet; benzidine, aniline dyes, azo and phthalocyanide dyes

Optical brighteners: Potassium salts of 4,4'-diaminostilbene-2,2'-disulphonic acid

Wire protecting, washing, and pitch removing agents: Compounds of mercaptobenzothiazole and imidazole, butyldiglycol, sodium hydroxide, chlorinated phenols until the 1960 s, trichloroethylene (from the 1950s to early 1970s), acetone, turpentine, toluene, phosphoric acid

Slime controlling agents:

3,5-Dimethyl-1,3,5,2H-tetrahydrothiodiazine-2-thione, mercaptobenzothiazole, 1,4-bis-bromoacetoxy-2-butene 2,2'-dibromo-3-nitrilopropionamide, diethyleneglycol, methylene-bisthiocyanate, dimethylformamide, potassium hydroxide, tetrahydrofurfurol

Coating agents: Kaolin, calcium carbonate, titanium dioxide, aluminium hydroxide, talc, carboxymethylcellulose, polyvinylalcohol, styrenebutadiene latex, acrylic latexes, polyvinylacetate

Maintenance department: Trichloroethylene (from 1950s to early 1970s), toluene, styrene, other aromatic compounds, white spirit, epoxy resins, asbestos, mineral oils, capacitor and transformer oil, welding fumes, mercury (until early 1970s) rinated phenols, but they were not exposed to pulp and paper chemicals. ${ }^{12}$ Their general living conditions differed little from those of the pulp and paper workers.

When the study period began (1 January 1945), 1657 of the total of 4810 workers studied (table 3) were employed and working for the company. The study population consisted of all those workers who had been working continuously for at least one year during the study period (1 January 1945 to 31 December 1961). They were grouped into the six subcohorts according to the longest continuous working period in a department belonging to one of the six subcohorts. Some workers had also worked continuously for at least one year in departments belonging to other subcohorts and these working periods were added to the follow up years of the corresponding subcohorts. This is a routine method applied by the Finnish Cancer Registry. ${ }^{1617}$ Workers who had not been exposed to actual process conditions were excluded from the study.

The basic source of the data was the company employment files, where all changes of job or foremen for each of the approximately 50000 workers were recorded. These permanent files were up to date, which was verified by checking the material against the employer statistics of the company. It was, therefore, possible to exclude from the study population all those who had worked, even for a short period, outside their regular working environment in the company. This was done in order to have well defined exposures. The personal data, including the follow up for death by 31 December 1981, were confirmed from the National Population Register and, when necessary, in local population registers. Retirement or changes of job did not affect the follow up. The cause of death was retrieved through the Central Statistical Office. Information was also obtained from Statistics Sweden and from the authorities in Norway, Denmark, Canada, and Australia.

All members of the cohorts were identified. The follow up was complete for all those who were still living, for those who had died in Finland, and for most of those who had emigrated. At the end of 1981, 3289 workers were alive and 1505 dead; $16(0.3 \%)$ were lost to follow up because they had left Finland for places with inadequate registries.

The person-years were calculated until death, the closing date of the study (31 December 1981), or (for the 16 cases lost to follow up) the date of emigration. Based on the follow up, those with a follow up time of 0-5 years and those with a follow up time of more than five years were analysed separately. This was done because five years is probably too short as a latency time for occupational cancer and also in a group of short follow up factors related to previous 
exposures other than pulp and paper work would be expected to have their maximum effect.

The expected numbers of deaths, calculated by five year age groups and five year calendar periods, were calculated for all main classes of the 8th revision of the International Classification of Diseases (except for classes XI, XIV, and XV) and for two specific causes of death: ischaemic heart disease (ICD 410-414) and stomach and duodenal ulcers (ICD 531-532). ${ }^{18}$ The latter were of interest because a higher frequency of gastrointestinal symptoms has been reported among shift workers - for example, by Angersbach et al $^{19}$-and the subjects in this study worked mostly in three shifts. The general Finnish population was used as reference. The age, sex, and calendar period specific numbers of person-years at risk in each subcohort were multiplied by the corresponding mortality rates. Standardised mortality ratios were obtained as the ratios of the observed to $\frac{2}{3}$ the expected numbers of cases. The Poisson distribu- $\mathbb{\Phi}$

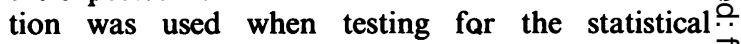
significance of the differences between the observed $\overrightarrow{\vec{F}}$. and expected numbers of deaths and when calculating the $95 \%$ confidence intervals for SMRs.

Smoking causes both lung cancer and ischaemic $\frac{\bar{\sigma}}{\bar{\omega}}$. heart disease and is a major potential confounder $\overrightarrow{\widetilde{\sigma}}$ when studying the association between occupational $\propto$ factors and these diseases. Information about smok- $\tilde{\omega}$ ing habits was, therefore, requested from a stratified $\overrightarrow{0}$ random sample of the study population, especially for $\vec{A}$ $1956 .{ }^{20}$ Nineteen fifty six was selected because it was $\vec{\rho}$ the year that Karvonen et al had studied the preva- $\stackrel{\circ}{\circ}$ lence of cigarette smoking in a Finnish population, ${ }^{21} \Phi$ it was conveniently in the middle of the study period, and there had been a general strike, clearly remembered by most people, in Finland that year. A total of $\theta$

Table 3 Cohorts and person-years by department and sex

\begin{tabular}{|c|c|c|c|c|c|c|}
\hline \multirow[b]{2}{*}{ Department } & \multicolumn{2}{|l|}{ Men } & \multicolumn{2}{|l|}{ Women } & \multicolumn{2}{|l|}{ Total } \\
\hline & $\begin{array}{l}\text { No of } \\
\text { workers }\end{array}$ & $\begin{array}{l}\text { Person- } \\
\text { years }\end{array}$ & $\begin{array}{l}\text { No of } \\
\text { workers }\end{array}$ & $\begin{array}{l}\text { Person- } \\
\text { years }\end{array}$ & $\begin{array}{l}\text { No of } \\
\text { workers }\end{array}$ & $\begin{array}{l}\text { Person- } \\
\text { years }\end{array}$ \\
\hline $\begin{array}{l}\text { Pulp and paper: } \\
\text { Sulphite mill } \\
\text { Sulphate mill } \\
\text { Paper mill } \\
\text { Board mill } \\
\text { Maintenance department } \\
\text { Power plant } \\
\text { Sawmill } \\
\text { Total }\end{array}$ & $\begin{array}{r}2696 \\
212 \\
501 \\
179 \\
648 \\
776 \\
380 \\
518 \\
3214\end{array}$ & $\begin{array}{r}70680 \\
6393 \\
16952 \\
5765 \\
18685 \\
34408 \\
11077 \\
20265 \\
90945\end{array}$ & $\begin{array}{r}824 \\
84 \\
226 \\
213 \\
218 \\
54 \\
29 \\
772 \\
1596\end{array}$ & $\begin{array}{r}23096 \\
3238 \\
7537 \\
7347 \\
5949 \\
2860 \\
956 \\
15926 \\
39022\end{array}$ & $\begin{array}{r}3520 \\
296 \\
727 \\
392 \\
866 \\
830 \\
409 \\
1290 \\
4810\end{array}$ & 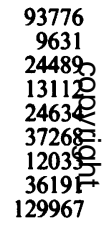 \\
\hline
\end{tabular}

Table 4 Observed and expected numbers of cause specific deaths and the corresponding SMRs with $95 \%$ confidence intervals by sex, compared with the population of Finland, in workers employed in the pulp and paper industry

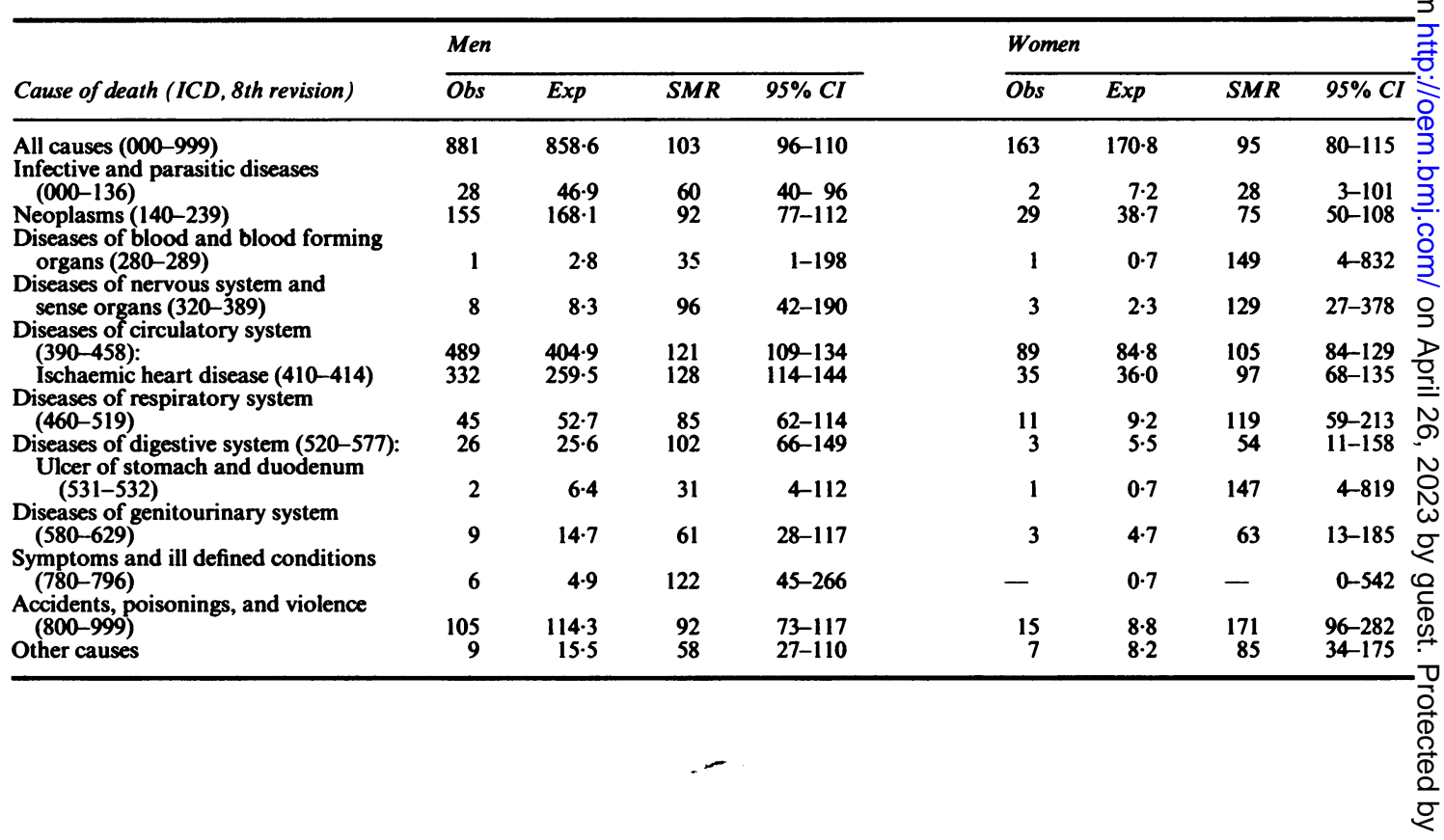


801 questionnaires was sent, 264 of them to relatives of dead workers. The reply rate was $82 \cdot 9 \%$.

\section{Results}

In the whole pulp and paper cohort the observed numbers of all deaths among men who had worked continuously for at least one year in a department belonging to any of the six subcohorts $(n=881)$ were a little higher than expected $(n=858.6)$ and among women a little lower (table 4). Owing to an excess of deaths from ischaemic heart disease among men (332 obs, 259.5 exp, SMR 128, p < 0.01), however, there were 489 deaths from diseases of the circulatory system among the men as against the 404.9 expected (SMR 121, p < 0.01). A deficit of deaths from infec-

Table 5 Observed and expected numbers of cause specific deaths and corresponding SMRs with $95 \%$ confidence intervals in men employed in the sulphite and sulphate mill, compared with the population of Finland

\begin{tabular}{|c|c|c|c|c|c|c|c|c|}
\hline \multirow[b]{2}{*}{ Cause of death (ICD, 8th revision) } & \multicolumn{4}{|c|}{ Sulphite mill } & \multicolumn{4}{|c|}{ Sulphate mill } \\
\hline & $\overline{O b s}$ & $\operatorname{Exp}$ & $S M R$ & $95 \% \mathrm{CI}$ & $\overline{O b s}$ & $\operatorname{Exp}$ & $S M R$ & $95 \% \cdot C I$ \\
\hline $\begin{array}{l}\text { All causes }(000-999) \\
\text { Infective and parasitic diseases }\end{array}$ & 119 & $121 \cdot 2$ & 98 & $78-124$ & 244 & $214 \cdot 4$ & 114 & $99-132$ \\
\hline $\begin{array}{l}(000-136) \\
\text { Neoplasms }(140-239) \\
\text { Diseases of blood and blood forming }\end{array}$ & $\begin{array}{r}1 \\
22\end{array}$ & $\begin{array}{r}6 \cdot 1 \\
25 \cdot 1\end{array}$ & $\begin{array}{l}16 \\
88\end{array}$ & $\begin{array}{r}0-91 \\
55-133\end{array}$ & $\begin{array}{r}6 \\
38\end{array}$ & $\begin{array}{l}11 \cdot 3 \\
42 \cdot 7\end{array}$ & $\begin{array}{l}53 \\
89\end{array}$ & $\begin{array}{r}19-115 \\
63-122\end{array}$ \\
\hline $\begin{array}{l}\text { organs }(280-289) \\
\text { Diseases of nervous system and }\end{array}$ & 1 & $0 \cdot 4$ & 244 & $6-136$ & 0 & 0.7 & - & $0-542$ \\
\hline $\begin{array}{l}\text { sense organs (320-389) } \\
\text { Diseases of circulatory system }\end{array}$ & 2 & $1 \cdot 1$ & 190 & $23-688$ & 2 & $2 \cdot 0$ & 98 & $12-354$ \\
\hline $\begin{array}{l}\text { (390-458): } \\
\text { Ischaemic heart disease }(410-414) \\
\text { Diseases of respiratory system }\end{array}$ & $\begin{array}{l}69 \\
50\end{array}$ & $\begin{array}{l}60 \cdot 6 \\
38 \cdot 1\end{array}$ & $\begin{array}{l}114 \\
131\end{array}$ & $\begin{array}{l}89-144 \\
97-173\end{array}$ & $\begin{array}{r}143 \\
96\end{array}$ & $\begin{array}{r}102 \cdot 1 \\
67 \cdot 6\end{array}$ & $\begin{array}{l}140 \\
142\end{array}$ & $\begin{array}{l}116-170 \\
115-174\end{array}$ \\
\hline $\begin{array}{l}\text { (460-519) } \\
\text { Diseases of digestive system (520-577): }\end{array}$ & $\begin{array}{r}13 \\
0\end{array}$ & $\begin{array}{l}8 \cdot 4 \\
3 \cdot 4\end{array}$ & 155 & $\begin{array}{r}83-265 \\
0-107\end{array}$ & $\begin{array}{r}15 \\
4\end{array}$ & $\begin{array}{r}12 \cdot 6 \\
6 \cdot 4\end{array}$ & $\begin{array}{r}119 \\
63\end{array}$ & $\begin{array}{l}67-196 \\
17-161\end{array}$ \\
\hline $\begin{array}{l}\text { (531-532) } \\
\text { Diseases of genitourinary system }\end{array}$ & $\mathbf{0}$ & 0.9 & - & $0-397$ & 1 & 1.6 & 63 & $2-348$ \\
\hline $\begin{array}{l}(580-629) \\
\text { Symptoms and ill defined conditions }\end{array}$ & $\mathbf{0}$ & $2 \cdot 2$ & - & $0-169$ & 3 & $3 \cdot 4$ & 87 & $18-256$ \\
\hline $\begin{array}{l}(780-796) \\
\text { Accidents, poisonings, and violence }\end{array}$ & $\mathbf{0}$ & 0.7 & - & $0-520$ & 2 & $1 \cdot 1$ & 187 & 23-675 \\
\hline $\begin{array}{l}(800-999) \\
\text { Other causes }\end{array}$ & $\begin{array}{r}10 \\
1\end{array}$ & $\begin{array}{r}11 \cdot 2 \\
1.9\end{array}$ & $\begin{array}{l}89 \\
52\end{array}$ & $\begin{array}{r}43-164 \\
1-290\end{array}$ & $\begin{array}{r}31 \\
0\end{array}$ & $\begin{array}{r}28 \cdot 3 \\
3 \cdot 8\end{array}$ & 110 & $\begin{array}{r}75-156 \\
0-96\end{array}$ \\
\hline
\end{tabular}

Table 6 Observed and expected numbers of cause specific deaths and corresponding SMRs with $95 \%$ confidence intervals in men employed in the paper and board mills, compared with the population of Finland

\begin{tabular}{|c|c|c|c|c|c|c|c|c|}
\hline \multirow[b]{2}{*}{ Cause of death (ICD, 8th revision) } & \multicolumn{4}{|c|}{ Paper mill } & \multicolumn{4}{|c|}{ Board mill } \\
\hline & $\overline{O b s}$ & $\operatorname{Exp}$ & $S M R$ & $95 \% C I$ & $\overline{O b s}$ & $\operatorname{Exp}$ & $S M R$ & $95 \% \mathrm{CI}$ \\
\hline $\begin{array}{l}\text { All causes }(000-999) \\
\text { Infective and parasitic diseases }\end{array}$ & 88 & $83 \cdot 2$ & 106 & $85-130$ & 225 & $231 \cdot 4$ & 97 & $84-114$ \\
\hline $\begin{array}{l}(000-136) \\
\text { Neoplasms }(140-239) \\
\text { Diseases of blood and blood forming }\end{array}$ & $\begin{array}{r}2 \\
19\end{array}$ & $\begin{array}{r}4 \cdot 6 \\
16 \cdot 4\end{array}$ & $\begin{array}{r}43 \\
116\end{array}$ & $\begin{array}{r}5-157 \\
70-181\end{array}$ & $\begin{array}{r}4 \\
55\end{array}$ & $\begin{array}{r}8 \cdot 1 \\
47 \cdot 3\end{array}$ & $\begin{array}{r}49 \\
116\end{array}$ & $\begin{array}{l}13-127 \\
88-151\end{array}$ \\
\hline $\begin{array}{l}\text { organs }(280-289) \\
\text { Diseases of nervous system and }\end{array}$ & 0 & 0.3 & - & $0-1272$ & 0 & 0.7 & - & $0-568$ \\
\hline $\begin{array}{l}\text { sense organs (320-389) } \\
\text { Diseases of circulatory system }\end{array}$ & 2 & 0.8 & 260 & 31-938 & 2 & $2 \cdot 1$ & 93 & 11-338 \\
\hline $\begin{array}{l}(390-458): \\
\text { Ischaemic heart disease (410-414) } \\
\text { Diseases of respiratory system }\end{array}$ & $\begin{array}{l}53 \\
34\end{array}$ & $\begin{array}{l}40 \cdot 1 \\
24 \cdot 7\end{array}$ & $\begin{array}{l}132 \\
138\end{array}$ & $\begin{array}{l}99-173 \\
95-193\end{array}$ & $\begin{array}{r}111 \\
81\end{array}$ & $\begin{array}{r}113 \cdot 0 \\
74 \cdot 3\end{array}$ & $\begin{array}{r}98 \\
109\end{array}$ & $\begin{array}{l}80-122 \\
87-136\end{array}$ \\
\hline $\begin{array}{l}\text { (460-519) } \\
\text { Diseases of digestive system (520-577): } \\
\text { Ulcer of stomach and duodenum }\end{array}$ & $\begin{array}{l}\mathbf{0} \\
\mathbf{3}\end{array}$ & $\begin{array}{l}5 \cdot 6 \\
2 \cdot 4\end{array}$ & $\overline{123}$ & $\begin{array}{r}0- \\
25-361\end{array}$ & $\begin{array}{r}13 \\
9\end{array}$ & $\begin{array}{r}14 \cdot 6 \\
6 \cdot 7\end{array}$ & $\begin{array}{r}89 \\
135\end{array}$ & $\begin{array}{l}47-152 \\
62-256\end{array}$ \\
\hline $\begin{array}{l}\text { (531-532) } \\
\text { Diseases of genitourinary system }\end{array}$ & 0 & 0.6 & - & $0-586$ & 0 & 1.6 & 一 & $0-238$ \\
\hline $\begin{array}{l}(580-629) \\
\text { Symptoms and ill defined conditions }\end{array}$ & 0 & 1.5 & - & $0-240$ & 2 & $3 \cdot 7$ & 55 & $7-197$ \\
\hline $\begin{array}{l}(780-796) \\
\text { Accidents, poisonings, and violence }\end{array}$ & 2 & 0.6 & 357 & $43-1290$ & 0 & 0.9 & - & $0-424$ \\
\hline $\begin{array}{c}(800-999) \\
\text { Other causes }\end{array}$ & $\begin{array}{l}7 \\
0\end{array}$ & $\begin{array}{l}9 \cdot 5 \\
1 \cdot 4\end{array}$ & $\underline{74}$ & $\begin{array}{r}30-152 \\
0-258\end{array}$ & $\begin{array}{r}27 \\
2\end{array}$ & $\begin{array}{r}30 \cdot 1 \\
4 \cdot 3\end{array}$ & $\begin{array}{l}90 \\
46\end{array}$ & $\begin{array}{r}59-130 \\
6-167\end{array}$ \\
\hline
\end{tabular}


tive and parasitic diseases was noted in both sexes, but especially among the men ( 28 obs, 46.9 exp, SMR $60, \mathrm{p}<0.01)$. There was a deficit of deaths from 6.4 exp, SMR 31). An excess of deaths from accidents, poisonings, and violence was recorded among the women but not among the men.

In the sulphite mill subcohort (table 5) there was an excess of deaths from ischaemic heart disease and from (non-malignant) diseases of the respiratory system for the men, but the figures were without statistical significance. The men showed a deficit of deaths from infective and parasitic diseases ( 1 obs, $6 \cdot 1$ exp, SMR 16, p < 0.05). In the sulphate mill subcohort (table 5) the men showed a pronounced excess of obs, 102.1 exp, SMR 140, p < 0.01), mainly owing to deaths from ischaemic heart disease (96 obs, $67.6 \mathrm{exp}$, SMR 142, p < 0.01). In the paper mill subcohort (table 6) the men showed non-significant excesses of deaths from diseases of the circulatory system and from ischaemic heart disease and a statistically significant deficit of deaths from non-malignant respiratory diseases $(0$ obs, 5.6 exp, p $<0.01)$.

Among the board mill workers (table 6) there were no pronounced excesses or deficits for the men. In the maintenance department subcohort (table 7) there were 170 observed deaths from ischaemic heart disease for the men as against 143.7 expected (SMR 118, $\mathrm{p}<0.05$ ). In the power plant subcohort (table 7) there was a pronounced excess of deaths from diseases of the circulatory system for the men $(93$ obs, stomach and duodenal ulcers among the men $(2 \mathrm{obs}$, deaths from diseases of the circulatory system (143

64.2 exp, SMR 145, p < 0.01), mainly because of an excess of deaths from ischaemic heart disease $(67 \mathrm{obs}$, 42.5 exp, SMR 158, p < 0.01).

For the women in the sulphite mill and board mill subcohorts there was a slight excess of deaths from diseases of the circulatory system owing to deaths from ischaemic heart disease. The observed numbers of all deaths for the women did not differ greatly from those expected in any of the subcohorts (table 8). There were no pronounced changes among the men or women in the mortality pattern by follow up time in any of the subcohorts.

The mortality rates in the sawmill reference cohort (table 9) differed in some respects from those among the pulp and paper workers. In the sawmill cohort the observed number of all deaths among the men $(\mathrm{n}=320)$ was considerably lower (SMR 85, $\mathrm{p}<0.01)$ than that expected $(n=378.4)$, nor was there an excess of deaths from diseases of the circulatory sys-

Table 8 Observed and expected numbers of deaths from all causes and the corresponding SMRs with $95 \%$ confidence intervals in women by pulp and paper subcohorts compared with the population of Finland

\begin{tabular}{llccc}
\hline Subcohort & Obs & Exp & SMR & $95 \%$ CI \\
\hline Sulphite mill & 31 & $28 \cdot 5$ & 109 & $74-1550$ \\
Sulphate mill & 48 & $54 \cdot 5$ & 88 & $65-1170$ \\
Paper mill & 63 & $72 \cdot 4$ & 87 & $67-111$ \\
Board mill & 26 & $26 \cdot 5$ & 98 & $64-144 \overline{-}$ \\
Maintenance department & 34 & 28.6 & 119 & $82-166 \beth$ \\
Power plant & 11 & $11 \cdot 3$ & 98 & $49-174$ \\
\hline
\end{tabular}

Table 7 Observed and expected numbers of cause specific deaths and corresponding SMRs with $95 \%$ confidence intervals in men employed in the maintenance department and power plant, compared with the population of Finland

\begin{tabular}{|c|c|c|c|c|c|c|c|c|}
\hline \multirow[b]{2}{*}{ Cause of death (ICD, 8th revision) } & \multicolumn{4}{|c|}{ Maintenance department } & \multicolumn{4}{|c|}{ Power plant } \\
\hline & $\overline{O b s}$ & $\operatorname{Exp}$ & $S M R$ & $95 \% C I$ & $\overline{\text { Obs }}$ & $\operatorname{Exp}$ & SMR & $95 \% C I$ \\
\hline $\begin{array}{l}\text { All causes (000-999) } \\
\text { Infective and parasitic diseases }\end{array}$ & 453 & $467 \cdot 1$ & 97 & $88-108$ & 150 & 133.4 & 112 & $95-132$ \\
\hline $\begin{array}{l}\text { (000-136) } \\
\text { Neoplasms }(140-239) \\
\text { Diseases of blood and blood forming }\end{array}$ & $\begin{array}{l}17 \\
84\end{array}$ & $\begin{array}{l}24 \cdot 7 \\
93 \cdot 6\end{array}$ & $\begin{array}{l}69 \\
90\end{array}$ & $\begin{array}{l}40-110 \\
72-111\end{array}$ & $\begin{array}{r}5 \\
20\end{array}$ & $\begin{array}{r}5 \cdot 6 \\
26 \cdot 6\end{array}$ & $\begin{array}{l}89 \\
75\end{array}$ & $\begin{array}{l}29-207 \\
46-116\end{array}$ \\
\hline organs $(280-289)$ & 0 & 1.5 & - & $0-243$ & $\mathbf{0}$ & 0.4 & - & $0-971$ \\
\hline $\begin{array}{l}\text { Diseases of nervous system and } \\
\text { sense organs (320-389) } \\
\text { Diseases of circulatory system }\end{array}$ & 4 & $4 \cdot 4$ & 91 & $25-233$ & 1 & $1 \cdot 3$ & 80 & $2-446$ \\
\hline $\begin{array}{l}\text { (390-458): } \\
\text { Ischaemic heart disease (410-414) }\end{array}$ & $\begin{array}{l}252 \\
170\end{array}$ & $\begin{array}{l}224 \cdot 3 \\
143 \cdot 7\end{array}$ & $\begin{array}{l}112 \\
118\end{array}$ & $\begin{array}{r}98-129 \\
101-138\end{array}$ & $\begin{array}{l}93 \\
67\end{array}$ & $\begin{array}{l}64 \cdot 2 \\
42 \cdot 5\end{array}$ & $\begin{array}{l}145 \\
158\end{array}$ & $\begin{array}{l}117-178 \\
122-200\end{array}$ \\
\hline $\begin{array}{l}\text { Diseases of respiratory system } \\
(460-519) \\
\text { Diseases of digestive system (520-577): } \\
\text { Ulcer of stomach and duodenum }\end{array}$ & $\begin{array}{l}20 \\
15\end{array}$ & $\begin{array}{l}29 \cdot 8 \\
13 \cdot 7\end{array}$ & $\begin{array}{r}67 \\
110\end{array}$ & $\begin{array}{l}41-104 \\
61-181\end{array}$ & $\begin{array}{l}7 \\
8\end{array}$ & $\begin{array}{l}8 \cdot 0 \\
4 \cdot 0\end{array}$ & $\begin{array}{r}88 \\
202\end{array}$ & $\begin{array}{l}35-181 \\
87-398\end{array}$ \\
\hline $\begin{array}{l}\text { (531-532) } \\
\text { Diseases of genitourinary system }\end{array}$ & $\mathbf{0}$ & 3.5 & - & $0-106$ & 1 & 1.0 & 100 & $3-586$ \\
\hline $\begin{array}{l}\text { Diseases of genitourinary system } \\
(580-629) \\
\text { Symptoms and ill defined conditions }\end{array}$ & 7 & 7.9 & 88 & $35-182$ & 1 & $2 \cdot 1$ & 48 & $1-268$ \\
\hline $\begin{array}{l}(780-796) \\
\text { Accidents, poisonings, and violence }\end{array}$ & 2 & $2 \cdot 5$ & 80 & $10-289$ & 0 & 0.6 & - & $0-636$ \\
\hline $\begin{array}{l}(800-999) \\
\text { Other causes }\end{array}$ & $\begin{array}{r}44 \\
8\end{array}$ & $\begin{array}{r}56 \cdot 6 \\
8 \cdot 1\end{array}$ & $\begin{array}{l}78 \\
99\end{array}$ & $\begin{array}{l}56-104 \\
43-194\end{array}$ & $\begin{array}{r}15 \\
0\end{array}$ & $\begin{array}{r}18 \cdot 2 \\
2 \cdot 5\end{array}$ & $\underline{82}$ & $\begin{array}{r}46-136 \\
0-148\end{array}$ \\
\hline
\end{tabular}


Table 9 Observed and expected numbers of cause specific deaths and corresponding SMRs with $95 \%$ confidence intervals by sex, in sawmill workers, compared with the population of Finland

\begin{tabular}{|c|c|c|c|c|c|c|c|c|}
\hline \multirow[b]{2}{*}{ Cause of death (ICD, 8th revision) } & \multicolumn{4}{|l|}{ Men } & \multicolumn{4}{|c|}{ Women } \\
\hline & Obs & $\operatorname{Exp}$ & $S M R$ & $95 \% C I$ & Obs & $\operatorname{Exp}$ & $S M R$ & $95 \% C I$ \\
\hline $\begin{array}{l}\text { All causes }(000-999) \\
\text { Infective and parasitic diseases }\end{array}$ & 320 & $378 \cdot 4$ & 85 & $76-94$ & 141 & $138 \cdot 1$ & 102 & $85-124$ \\
\hline $\begin{array}{l}(000-136) \\
\text { Neoplasms }(130-239) \\
\text { Diseases of blood and blood forming }\end{array}$ & $\begin{array}{r}5 \\
62\end{array}$ & $\begin{array}{l}18 \cdot 9 \\
75 \cdot 5\end{array}$ & $\begin{array}{l}26 \\
82\end{array}$ & $\begin{array}{r}9-62 \\
63-105\end{array}$ & $\begin{array}{r}0 \\
33\end{array}$ & $\begin{array}{r}6 \cdot 1 \\
31 \cdot 6\end{array}$ & $\overline{104}$ & $\begin{array}{r}0-60 \\
72-146\end{array}$ \\
\hline $\begin{array}{l}\text { organs }(280-289) \\
\text { Diseases of nervous system and }\end{array}$ & 1 & $1 \cdot 3$ & 77 & $2-429$ & 1 & 0.5 & 185 & $5-1032$ \\
\hline $\begin{array}{l}\text { sense organs }(320-389) \\
\text { Diseases of circulatory system }\end{array}$ & 3 & $3 \cdot 2$ & 93 & $19-271$ & 1 & 1.8 & 55 & $1-304$ \\
\hline $\begin{array}{l}(390-458): \\
\text { Ischaemic heart disease (410-414) } \\
\text { Diseases of respiratory system }\end{array}$ & $\begin{array}{l}180 \\
105\end{array}$ & $\begin{array}{l}189 \cdot 3 \\
114 \cdot 2\end{array}$ & $\begin{array}{l}95 \\
92\end{array}$ & $\begin{array}{l}82-110 \\
73-117\end{array}$ & $\begin{array}{l}76 \\
38\end{array}$ & $\begin{array}{l}68 \cdot 5 \\
29 \cdot 4\end{array}$ & $\begin{array}{l}111 \\
129\end{array}$ & $\begin{array}{l}87-139 \\
92-178\end{array}$ \\
\hline $\begin{array}{l}\text { Diseases of digestive system (520-577): } \\
\text { Ulcer of stomach and duodenum }\end{array}$ & $\begin{array}{r}16 \\
7\end{array}$ & $\begin{array}{l}27 \cdot 3 \\
10 \cdot 8\end{array}$ & $\begin{array}{l}59 \\
65\end{array}$ & $\begin{array}{l}33-95 \\
26-133\end{array}$ & $\begin{array}{l}9 \\
2\end{array}$ & $\begin{array}{l}7 \cdot 5 \\
4 \cdot 5\end{array}$ & $\begin{array}{r}121 \\
45\end{array}$ & $\begin{array}{r}55-229 \\
5-161\end{array}$ \\
\hline $\begin{array}{l}(531-532) \\
\text { Diseases of genitourinary system }\end{array}$ & 1 & $2 \cdot 9$ & 35 & $1-195$ & 0 & $0 \cdot 6$ & - & $0-659$ \\
\hline $\begin{array}{l}(580-629) \\
\text { Symptoms and ill defined conditions }\end{array}$ & 6 & $7 \cdot 4$ & 81 & $30-176$ & 6 & $3 \cdot 8$ & 157 & $57-341$ \\
\hline $\begin{array}{l}(780-796) \\
\text { Accidents, poisonings, and violence } \\
(800-999)\end{array}$ & 0 & $2 \cdot 9$ & - & $0-126$ & 0 & $0 \cdot 6$ & - & $0-671$ \\
\hline $\begin{array}{l}(800-999) \\
\text { Other causes }\end{array}$ & $\begin{array}{r}34 \\
6\end{array}$ & $\begin{array}{r}35 \cdot 2 \\
6 \cdot 5\end{array}$ & $\begin{array}{l}97 \\
93\end{array}$ & $\begin{array}{l}67-135 \\
34-202\end{array}$ & $\begin{array}{l}6 \\
7\end{array}$ & $\begin{array}{l}6 \cdot 5 \\
6 \cdot 6\end{array}$ & $\begin{array}{r}92 \\
106\end{array}$ & $\begin{array}{l}34-201 \\
43-219\end{array}$ \\
\hline
\end{tabular}

Table 10 Prevalence of smoking in the 15-69 year age group in 1956 by department and sex

\begin{tabular}{lcc}
\hline Department & Men & Women \\
\hline Pulp and paper: & $55 \cdot 1$ & 6.9 \\
Sulphite mill & $55 \cdot 2$ & 3.4 \\
Sulphate mill & 80.0 & $6 \cdot 3$ \\
Paper mill & 61.9 & $5 \cdot 3$ \\
Board mill & $54 \cdot 2$ & $11 \cdot 5$ \\
Maintenance department & 46.8 & $10 \cdot 0$ \\
Power plant & 50.5 & 20.0 \\
Sawmill & $51 \cdot 3$ & $9 \cdot 1$ \\
\hline
\end{tabular}

tem or from ischaemic heart disease. There was a slight increase in deaths from ischaemic heart disease among the women in the sawmill cohort and a significant deficit of deaths from infective and parasitic diseases among both sexes (men: 5 obs, 18.9 exp, SMR 26, p < 0.01; women: 0 obs, 6.1 exp, p < 0.01). A more conspicuous deficit of deaths from nonmalignant diseases of the respiratory system was noted among the men in the sawmill cohort (16 obs, 27.3 exp, SMR 59, p < 0.05) than among the pulp and paper workers.

The prevalence of smoking in 1956 among men employed by this company (table 10) was similar for most of the subcohorts, except for the sulphate mill subcohort in which it was higher. In the present study the prevalence of smoking had decreased among men since 1956 but increased among women. At the end of $1981,37.3 \%$ of the men (age group 15-69) and 15\% of the women in the total pulp and paper cohort smoked. In 1956 the prevalence of smoking in the sawmill cohort was of the same magnitude as among the pulp and paper workers, but in 1981 the prevalence figures $(51.4 \%$ for men and $8.3 \%$ for women) showed that changes in smoking habits had not been as pronounced in the sawmill cohort as among the pulp and paper workers.

\section{Discussion}

Because of the multiple comparisons made in studies such as this, single statistically significant findings should be interpreted with caution. The slight excess of deaths from all causes among the men of the total pulp and paper cohort is noteworthy since mortality among industrial cohorts is usually below the expected level because of the "healthy worker effect." In the present study, however, two factors suggest a comparatively low healthy worker effect. Firstly, those who had left their jobs were also followed up and, secondly, the follow up period was relatively long. The excess total mortality may be attributed largely to the excess number of deaths from diseases of the circulatory system, and especially from ischaemic heart disease, that was found among the men of the total pulp and paper cohort. This excess was apparent among the men of the sulphite, sulphate, and paper mills, maintenance department, and power plant subcohorts but not in the sawmill cohort. The excess risk of coronary heart disease was most prominent in the power plant subcohort (SMR 158). The power plant departments of sulphate pulp mills include evaporation plants and recovery boilers, with 
hydrogen sulphide concentrations of up to $20 \mathrm{ppm}$ and methyl mercaptan concentrations of up to 5 ppm. ${ }^{22}$

Regional differences have been observed in death from ischaemic heart disease in Finland, the highest rates being in the east and the lowest in the south west. The mortality from ischaemic heart disease has been somewhat higher in the province of Kymi (age standardised annual mortality rate for men aged 35 to 64 per 100000 in 1969:540) than in the western part of the country (in the province of Turku and Pori the annual rate in 1969 was 365 ) but considerably lower than in North Karelia, where coronary mortality rates are high (annual rate in 1969:688). ${ }^{23-25}$ The fact that there was not an excess of deaths from diseases of the circulatory system or from ischaemic heart disease among the men of the sawmill cohort suggests that regional differences probably do not explain the excesses of these deaths among the pulp and paper workers.

Nevertheless, several confounders may also be implicated. The proportion of smokers among the men in the sulphate mill subcohort in the present study was higher $(80 \%)$ than in the other subcohorts, a finding that may partly explain the excess of cardiovascular deaths in this subcohort. Nevertheless, the proportions of smokers among men in other subcohorts with similar excesses of cardiovascular deaths did differ greatly from either the average in the pulp and paper cohort or from the proportion of smokers among Finnish men in general. ${ }^{21} 26$ The smoking figures presented by Karvonen et $^{a l^{21}}$ are, however, not directly comparable with those in the present study. They recorded a prevalence of $72.5 \%$ for cigarette smoking among men aged 20-59 years in rural east Finland.

Recall bias is probable in a survey on smoking habits 25 years ago, especially in the relatives of dead workers. The response rate for them was from $58.2 \%$ to $96.7 \%$ in different subcohorts and no workers in the survey had died without any living relatives. The response rate for workers still alive ranged from $82.3 \%$ to $94.2 \%$ in different subcohorts. So the reply percentage must be considered as satisfactory and as such not a cause of concern. Unfortunately, it is impossible to estimate what the effect or even the direction of the recall bias would be. In the case of a positive finding as in the present study underestimation of smoking habits would tend to cause a spurious association with work. The recall bias, however, is unlikely to be so great that it would change the direction of the results. The possible confounding effect of smoking is discussed in more detail in a separate paper. ${ }^{27}$ Despite the possible recall bias, it seems unlikely that the excess mortality may be attributed solely to differences in smoking habits.
Only rather scanty information was available on the serum cholesterol values or blood pressure levels $\frac{3}{\$}$ among the study population during the 1950s and ? 1960 s, but the records kept in occupational health $\vec{\Rightarrow}$ departments in more recent years do not give any reason to assume that these risk factors of coronary disease differed greatly between the study group and the general population.

Sulphur compounds are the most common of the $\stackrel{\mathbb{D}}{\circ}$ aetiological agents that may affect exposed workers in $\&$ the work environment of the pulp and paper mills $\vec{\circ}$ under study. The possible role of gaseous sulphur compounds, especially the hydrogen sulphide present in sulphate mills, ${ }^{22}$ in the pathogenesis of coronary heart disease has still not been established. Nevertheless, hydrogen sulphide at higher concentrations is known to affect the heart frequency and cause changes in the ECG. ${ }^{15}$ An excess of deaths from circulatory diseases has been reported in a proportionate mortality study ${ }^{14}$ but not in a follow up study on 271 pulp and paper workers. ${ }^{13}$

The deficit of deaths from infective and parasitic $\vec{C}$ diseases found in the pulp and paper cohort and in all the subcohorts is probably due mainly to the high standard of living among the employees and to the organised occupational health care. Probably also healthier people are selected for the industry, although the magnitude of this effect is not knowr $\infty$ The deficit of deaths from diseases of the respirato system found among the men in this study was consie tent with that reported earlier, ${ }^{14}$ although there were excesses of these deaths, possibly related to harmful agents in the ambient air, in the sulphite mill and sulphate mill subcohorts.

The present study did not find an excess of total deaths from accidents, poisonings, or violence, as reported in an earlier study. ${ }^{14}$ There was a deficit of deaths from stomach and duodenal ulcers, especially for men. In contrast to data reported earlier, ${ }^{14}$ there were fewer deaths from cancer than expected in the pulp and paper cohort. A separate cancer incidence study conducted on the same cohorts as in the present mortality study showed no excess risk of primary cancer in general but an excess risk of lung cancer among board mill workers in particular (40 obs, 18.1 exp, SIR 222) (the results will be published separately).

The principal finding of the present study was that there was an excess of deaths from diseases of the $N$ circulatory system and especially from ischaemic heart disease among the men in the total pulp and paper cohort, originating from the sulphite, sulphate, and paper mill, maintenance department, and power plant subcohorts. All these groups are exposed to gaseous sulphur compounds and some theories have been proposed for the possible aetiological role of 
these compounds. Since the common risk factors of coronary heart disease do not easily seem to explain this finding, occupational factors may be involved. In the future a further analysis on mortality by duration of employment is needed. Clearly also there are many difficulties in controlling for confounding in this type of retrospective study. Both experimental work and epidemiological studies are needed before definite conclusions may be drawn.

This study was supported by the Finnish Work Environment Fund. I gratefully acknowledge the help given by Dr Timo Hakulinen and Mr Eero Pukkala of the Finnish Cancer Registry and by Dr Kari Kurppa and especially Dr Sakari Tola of the Institute of Occupational Health in Helsinki. I thank Ms RiittaSisko Koskela and Ms Mirja Silventoinen of the Institute of Occupational Health in Helsinki and Dr Ann-Marie Bolander of Statistics Sweden for their help and Ms Merja-Liisa Sairanen and Ms Merja Matilainen of Enso-Gutzeit Oy for their technical help.

\section{References}

1 Statistical yearbook of Finland 1984. Helsinki: Central Statistical Office of Finland, 1985.

2 Pulp and paper. North American industry factbook 1980-1981. San Francisco: Miller Freeman Publications Inc, 1980.

3 Industrial statistics yearbook 1982. Vol 1. General industrial statistics. New York: United Nations, 1985.

4 Milham SJR, Hesser JE. Hodgkin's disease in woodworkers. Lancet 1967;ii:136-7.

5 Greene MH, Brinton LA, Fraumeni JF, D'Amico R. Familial and sporadic Hodgkin's disease associated with occupational wood exposure. Lancet 1978;ii:626-7.

6 Grufferman S, Duong T, Cole P. Occupation and Hodgkin's disease. JNCI 1976;57:1193-5.

7 Milham SJR. Occupational mortality in Washington State 1950-1971. Washington: US Government Printing Office, 1976. (DHEW (NIOSH) publ No 7776-175 A,B,C.)

8 Milham SJR. Neoplasia in the wood and pulp industry. Ann NY Acad Sci 1976;271:294-300.

9 Harrington JM, Blot WJ, Hoover RN, Housworth WJ, Heath CW, Fraumeni JFJR. Lung cancer in coastal Georgia: a death certificate analysis of occupation: brief communication. JNCI 1978;60:295-8.

10 Blot WJ, Fraumeni JFJR. Geographic patterns of lung cancer: industrial correlations. Am J Epidemiol 1976;103:539-50.

11 Menck HR, Henderson BE. Occupational differences in rates of lung cancer. J Occup Med 1976;18:797-801.

12 International Agency for Research on Cancer. Monographs on the evaluation of the carcinogenic risk of chemicals to humans. Vol 25. Wood, leather and some associated industries. Lyon: IARC, 1981

13 Ferris BGJR, Puleo S, Chen HY. Mortality and morbidity in a pulp and a paper mill in the United States: a ten-year followup. Br J Ind Med 1979;36:127-34.

14 Milham SJR, Demers RY. Mortality among pulp and paper workers. J Occup Med 1984;26:844-6.

15 Savolainen $H$. Nordiska expertgruppen för gränsvärdesdokumentation. 40. Dihydrogensulfid. Arbeta och Hälsa 1982;31. (In Swedish.)

16 Kilpikari I, Pukkala E, Lehtonen M, Hakama M. Cancer incidence among Finnish rubber workers. Int Arch Occup Environ Health 1982;51:65-71.

17 Kilpikari I. Mortality among male rubber workers in Finland. Arch Environ Health 1982;37:295-9.

18 World Health Organisation. Manual of the international statistical classification of diseases, injuries, and causes of death. (8th rev.) Vol 1. Geneva: WHO, 1967.

19 Angersbach D, Knauth P, Loskant H, Karvonen MJ, Undeutsch K, Rutenfranz J. A retrospective cohort study comparing complaints and diseases in day and shift workers. Int Arch Occup Environ Health 1980;45:127-40.

20 Cochran WG. Sampling techniques. New York: John Wiley \& Sons, 1963

21 Karvonen M, Orma E, Keys A, Fidanza F, Brozek J. Cigarette smoking, serum-cholesterol, blood-pressure, and body fatness. Observations in Finland. Lancet 1959;i:492-4.

22 Kangas J, Jäppinen P, Savolainen $H$. Exposure to hydrogen sulfide, mercaptans and sulfur dioxide in pulp industry. Am Ind Hyg Assoc J 1984;45:787-90.

23 Puska P. Sydän ja verisuonitautikuolleisuuden alueelliset erot Suomessa (regional differences in CVD mortality in Finland). Suomen Lääkärilehti 1972;27:3071-5. (In Finnish.)

24 Leppo K, Lindgren J, Ritamies M. Mortality trends in Finland in the 1960s. In: Yearbook of population research in Finland, XII, 1971. Helsinki: Population Research Institute, 1972.

25 Salonen JT, Puska P, Kottke TE, Tuomilehto J, Nissinen A. Decline in mortality from coronary heart disease in Finland from 1969 to 1979. Br Med J 1983;286:1857-60.

26 Poukkula A, Huhti E, Mäkäräinen $M$. Chronic respiratory disease among workers in a pulp mill. A ten-year follow-up study. Chest 1982;81:285-9.

27 Jäppinen P, Tola S. Smoking among Finnish pulp and paper workers-evaluation of its confounding effect on lung cancer and coronary heart disease rates. Scand J Work Environ Health 1986;12:619-26. 